\title{
Comparative Proximate Composition of Liza Falcipinnis and Sardinella Maderensis Smoked Using Improve Niomr and Locally Improvised Drum Kilns
}

\author{
Abu $\mathrm{OMG}^{{ }^{*}}$ and Olotu $\mathrm{C}^{2}$ \\ Department Of Fisheries, Faculty of Agriculture, University Of Port Harcourt, Choba, Rivers State, Nigeria.
}

Received: January 19, 2018; Accepted: January 31, 2018; Published: February 1, 2018

**orresponding author: Abu OMG, Department Of Fisheries, Faculty of Agriculture, University Of Port Harcourt, Choba, Rivers State, Nigeria; Tel+2348037112328; E-mail: ojoakinrotimi@gmail.com

\begin{abstract}
This study was carried out to determine and compare the proximate composition of smoked Liza falcipinnis and Sardinella maderensis using improved NIOMR and local drum smoking kilns. Data were collected in triplicates and analyzed using t-test. The values obtained from the proximate analysis of smoked L. falcipinnis using Drum kiln and the NIOMR kiln respectively were: Moisture $(11.70$ and 9.63$) \%$, Protein $(52.28$ and 61.60$) \%$, Ash $(14.30$ and $15.59) \%$, Carbohydrate (7.06 and 1.37)\%, Fibre (3.79 and 2.94)\%, Fat (12.93 and 8.24 )\% respectively, while smoked S. maderensis using Drum kiln and NIOMR kiln were: Moisture (10.22 and 7.71)\%, Protein (59.58 and 65.55)\%, Ash (19.00 and 18.20)\%, Carbohydrate (1.89 and 0.43$) \%$, Fibre (2.97 and 1.83)\%, Fat (6.35 and 6.29)\% respectively. From the result, moisture, carbohydrate, fibre and fat content of L. falcipinnis smoked with drum kiln was higher than that of the NIOMR kiln with exception to protein and ash which was higher using NIOMR kiln. While the protein and ash content of S.maderensis smoked with NIOMR kiln was higher than that of the drum kiln with exceptions to moisture, carbohydrate and fibre which was higher in the drum kiln. Therefore, the use of NIOMR kiln as against the drum kiln was recommended as it retained higher level of the proximate composition of L. falcipinnis and S. maderensis.
\end{abstract}

Keywords: Proximate composition; Smoking kiln; Fish; Processing; Preservation;

\section{Introduction}

Fish and fishery products are highly perishable, so the fishermen in Nigeria who mostly carryout artisanal based fishing, experience a high level of post-harvest losses of about $40 \%$ as some of their fish catch do not get to consumers in wholesome state [1]. The need for timely preservation of fish cannot be overemphasized as it is a very important part of commercial fisheries [2] . Fish spoilage or deterioration begins immediately the fish dies and if not properly handled and preserved goes to post harvest loss. Nigerian fishermen in attempt to preserve and process their catch use different smoking methods. The most common of these methods used in Rivers State is the drum kiln which does not have means of proper temperature regulation. This sometimes results in charring the fish during smoking.
Fish is an essential component of the diet of many Nigerians ranging from the poor to the rich. It is a highly nutritious food and it is particularly valued for its protein which is of high quantity compared to those of meat and egg [3]. About 25-30\% of the world fish catch is consumed in dried, salted, smoked form or product from a combination of these processing methods [4]. As earlier mentioned, smoking is the most common form or method of fish preservation in Nigerian. Although different locally made smoking equipment have been used by fishermen ranging from chokor kiln to banda, drum kiln and even the improved smoking kiln, the drum kiln is mostly used in Nigeria as it is easy to construct and use. Different methods of preservation have different effects on the nutritional composition of fish. This is because heating, freezing and exposure to high concentration of salt lead to chemical and physical changes and therefore digestibility is increased, due to protein denaturing but the content of thermo labile compounds and polysaturated fatty acids is often reduced [5].

Smoking also has its effect on the nutritive value of fish as high temperature denatures protein which is the major nutrient source from fish. Smoke is generated from wood by burning. Smoke has bacteriostatic, bactericidal and antioxidant functions while heat generated from the wood has dehydrating effect on the fish [6].The consumption of smoked fish is in Nigeria is very high, and consumers sometimes prefer smoked fish to the fresh ones but how nutritive is the smoked fish products using drum kiln that do not have temperature control remains questionable.

This research project will provide useful information on the proximate composition and the organoleptic properties of smoked Liza falcipinnis and Sardinella maderensis which will guide our preferential choice of fresh, dried using the drum kiln or the NIOMR smoking kiln. These fish species Liza falcipinnis and Sardinella maderensis are of high economic value in Rivers State in particular and Nigeria in general. The smoked form is loved by consumers and commands good market value. Accessing the proximate composition of the smoked and fresh form of these species will inform the public of the better preservation method 
that retains the highest nutrient composition of these fish species. This research is aimed at determining the proximate composition of two economically important fish species (Liza falcipinnis and Sardinella maderensis) in Choba fish market.

\section{Materials and Methods}

\section{Preparation of Fish Sample}

Samples of the fish species (Liza falcipinnis and Sardinella maderensis) were purchased from Choba fish market and the samples were weighed using a weighing scale and samples were collected in polyethylene bags with ice. The fish species were de-scalled, gutted and thoroughly washed, brined and smoked using drum kiln and the NIOMR smoking kiln. After which the dry samples were sent to NAFDAC for proximate analysis.

\section{Procedures of Proximate Analysis}

Samples for proximate analysis were prepared in triplicates for each of the two fish species and analysed following a procedure by AOAC [7]. The analysis methods employed were described as follows:

\section{Protein Determination}

Protein was determined using the semi-micro kjeldahl method. One gram sample from each of the two species was digested in a kjeldahl flask using 98\% sulphuric acid and a catalyst made from Potassium Sulphate and Cupric Sulphate. The sample was distilled and the distillate titrated using $0.05 \mathrm{M}$ Sodium hydroxide $(\mathrm{NaOH})$. Crude protein content was determined as nitrogen and multiplied by 6.25 (Protein contains 16\% nitrogen thus, 6.25 is $100 / 16$ ).

\section{Fat Determination}

Fat content was determined using Soxhlet ether extraction. Petroleum ether was added to $2.0 \mathrm{~g}$ sample of fish and placed in an extraction apparatus (a thimble). Extraction was carried out for 16 hours, after which the ether had evaporated to dryness and only fat remained in the flask. The amount of fat was obtained as the difference in the weight of the flask before and after drying off the ether.

\section{Moisture Determination}

One gram sample of ground fish was placed in a crucible and dried at 105 degrees Celsius to a constant weight after the initial weighing. Moisture content of the fish was calculated by subtracting the initial from the final weight of the fish sample.

\section{Ash Determination}

Two grams sample of ground fish was placed in a crucible then ashed at 600 degrees Celsius for 5 hours in carbolite muffle furnace then cooled to room temperature. The amount of ash was given by the difference in weight of the crucible before and after cooling.

\section{Data Analysis}

Data obtained from the study were entered into Microsoft
Excel and analysed using SPSS for Windows version 22.0 software. Treatment means of the two fish samples were compared using one way Analysis of Variance (ANOVA) at 5\% level of significance reported as mean standard edeviations ( \pm SD). Significantly different treatment means were separated using Tuckey test.

\section{Results}

The results of proximate composition of $\mathrm{L}$. falcipinnis are shown in Table 1; the moisture, carbohydrate, fibre and fat content of the mullet were higher in the Drum kiln than in the NOMR kiln while protein and ash content were higher in NIOMR kiln than in the Drum kiln. While that of S. maderensis is shown in Table 2; the moisture, ash, carbohydrate, fibre and fat content of the mullet were higher in the Drum kiln than in the NOMR kiln while protein content was higher in NIOMR kiln than in the Drum kiln.

Table 1: Proximate composition of Smoked Mullet using NIOMR and Drum kiln

\begin{tabular}{|c|c|c|}
\hline Proximate composition & Drum Kiln & NIOMR \\
\hline Moisture & $11.70 \pm 1.29^{\mathrm{b}}$ & $9.63 \pm 3.21^{\mathrm{a}}$ \\
\hline Protein & $52.28 \pm 1.43^{\mathrm{a}}$ & $61.60 \pm 3.33^{\mathrm{b}}$ \\
\hline Ash & $14.30 \pm 0.42^{\mathrm{a}}$ & $15.59 \pm 0.95^{\mathrm{a}}$ \\
\hline Carbohydrate & $7.06 \pm 2.36^{\mathrm{b}}$ & $1.37 \pm 0.34^{\mathrm{a}}$ \\
\hline Fiber & $3.79 \pm 0.98^{\mathrm{a}}$ & $2.94 \pm 0.12^{\mathrm{a}}$ \\
\hline Fat & $12.93 \pm 1.47^{\mathrm{b}}$ & $8.24 \pm 2.34^{\mathrm{a}}$ \\
\hline
\end{tabular}

Means within the roll with different superscripts are significantly different $(P<0.05)$

Table 2: Smoked Sardine using NIOMR and Drum kiln.

\begin{tabular}{|c|c|c|}
\hline $\begin{array}{c}\text { Proximate } \\
\text { composition }\end{array}$ & $\begin{array}{c}\text { Smoked S.Maderensis } \\
\text { Drum Kiln }\end{array}$ & $\begin{array}{c}\text { Smoked NIOMR } \\
\text { S.maderensis }\end{array}$ \\
\hline Moisture & $10.22 \pm 0.53^{\mathrm{b}}$ & $7.71 \pm 0.90^{\mathrm{a}}$ \\
\hline Protein & $59.58 \pm 2.58^{\mathrm{a}}$ & $65.55 \pm 0.60^{\mathrm{b}}$ \\
\hline Ash & $19.00 \pm 0.47^{\mathrm{a}}$ & $18.20 \pm 1.05^{\mathrm{a}}$ \\
\hline Carbohydrate & $1.89 \pm 1.16^{\mathrm{b}}$ & $0.43 \pm 0.21^{\mathrm{a}}$ \\
\hline Fiber & $2.97 \pm 0.98^{\mathrm{b}}$ & $1.83 \pm 0.56^{\mathrm{a}}$ \\
\hline Fat & $6.35 \pm 1.27^{\mathrm{a}}$ & $6.29 \pm 0.57^{\mathrm{a}}$ \\
\hline
\end{tabular}

Means within the roll with different superscripts are significantly different $(P<0.05)$

\section{Discussion}

The nutritional value of the freshwater fish has been reported to differ between species, sexes, sizes, season and geographical localities [8]. From the study, moisture content of smoked L.falcipinnis using drum and NIOMR kiln was $11.70 \%$ and $9.63 \%$, respectively this result showed that the L.falcipinnis smoked with NIOMR kiln lost more moisture than that of drum kiln. The percentage protein and ash in the L.falcipinnis smoked with NIOMR kiln was also higher than that of the drum kiln. While the carbohydrate, fibre and fat content of the L.falcipinnis smoked with drum kiln was higher than that of the NIOMR kiln. 
The moisture content of smoked S.maderensis with drum kiln was $10.22 \%$ which is lower than $7.71 \%$ for NIOMR kiln. The percentage protein and ash in the S. maderensis smoked with NIOMR kiln was also higher than that of the drum kiln. While the carbohydrate, fibre and fat content of the S.maderensis smoked with drum kiln was higher than that of the NIOMR kiln. The results obtained in the present study agreed with the value ranges recorded by Adebowale et al. [9], in the study of proximate composition of Nigeria smoked catfish

Moreover, Adewoye, and Omotosho [10] mentioned that proximate composition of fish varies with species, body size, season, environmental factors and nutritional status. The increase of the protein content in NIOMR smoking kiln may be due to steady and consistent product dehydration as a result of temperature regulation which concentrated the protein during the heat treatment of the fish, thus increasing the nutritive value of the fish, similar findings was also reported by, Kumolu et al [11], who compared crude protein levels of Clarias gariepinus dried with local cut drum oven and NSRRI developed smoking. Conversely, Fawole et al. [12], also reported that increase in protein may be attributed to the fact that fish are good source of crude protein and the difference in crude protein between the two kilns could be due to the regularity of temperature and absorption capacity of the fish.

The low ash, carbohydrate, fat, Nitrogen Free Extract (NFE), high protein and moisture content values obtained from the proximate analysis as shown in Table 1 and 2 agreed with other analysis carried out by earlier researchers such as , Kumolu et al. [11], and Adewoye, and Omotosho [10]. The significant increase in protein levels $(\mathrm{P}<0.05)$ in dried mullets and Sardinella maderensis, when compared with the raw fish, suggested that protein nitrogen was not lost during drying. It is has been observed that smoking increases protein content in fish due to heat dehydration which concentrates proteins thus increasing the nutritional value of the processed fish product

\section{Conclusions}

L. falcipinnis smoked with NIOMR kiln had an edge over L.falcipinnis smoked with drum kiln in terms of moisture and protein content of which fish is consumed for its protein value, this result is also the same for $\mathrm{S}$. maderensis smoked using NIOMR and drum kiln respectively. Therefore this result indicates that the NIOMR kiln enhances the nutritive values of both fish species than the drum kiln. With the conclusion stated above, I therefore recommend that; more studies should be carried out on these fish species as they are economically important.

\section{References}

1. Akande GR, Oladosu OS and Tobor JG. A comparative technical and economical appraisal of fish smoking: Two traditional ovens and a new improved Magbon-Alade oven. . FAO Fisheries Report. 1998;574:7075.

2. Pandey K and Shukla JP. Fish and fisheries published by Rakesh Kumar for Rastogi publication,India. 2005. pp: 499.

3. Ojutiku RO, Kolo RJ, Mhammed ML Comparative study of sun drying and solar tent drying of Hyperopisus bebeoccidentalis. Pak. J Nutr. 2009;8(7):955-957.

4. Aliya G, Humaid K, Nasser A, Sami G, Aziz K, Nashwa M, Ponerasseryss. Effects of the freshness of starting material on the final product of dried salted shark. Advan J Food Sci Technol. 2012;4(2):60-63

5. Chukwu O, Shaba IM . Effects of drying methods on proximate composition of catfish (Clarias gariepinus). World J Agric Sci. 2009;5(1):114-116.

6. Eyo AA. Fish processing Technology in the tropics. National Institute for Freshwater fisheries Research, Nigeria. 2001. Pages:403

7. AOAC . Official Methods of Analysis (18th edition) Association of Official Analytical, Chemists International, Maryland, USA. 2005.

8. Zenebe T, Ahigren G and Boberg, M. Fatty acid content of some freshwater fish commercial importance from tropical lakes in the Ethiopian rift valley.J Fish Biol.1998;53:987-1005. DOI: 10.1111/ j.1095-8649.1998.tb00458.x

9. Adebowale BA, Dongo, LN, Jayeola CO and Orisajo SB. Comparative quality assessment of fish (Clarias gariepinus) smoked with cocoa pod husk and three other different smoking materials. Journal of Food Technology. 2008;6(1):5-8.

10. Adewoye, S. O. and Omotosho, J. S. Nutrient composition of some freshwater fishes in Nigeria.Bioscience Research Communications. 1997;11(4):333-337.

11. Kumolu-Johnson CA, Aladetohun NF, Ndimele PE. The effects of smoking on the nutritional qualities and shelf life of Clarias gariepinus . Afr J Biotechnol. 2010;9:73-76

12. Fawole 00, Ogundiran MA, Ayandiran TA, Olagunju OF. Proximate and mineral composition of some selected fresh water fishes in Nigeria. International Journal of Food Safety. 2007;9:52-55. 